\title{
Water, heat, and airborne pollutants effects on transpiration of urban trees
}

\author{
Hua Wang, Zhiyun Ouyang*, Weiping Chen, Xiaoke Wang, Hua Zheng, Yufen Ren \\ State Key Laboratory of Urban and Regional Ecology, Research Center for Eco-Environmental Sciences, Chinese Academy of Sciences, Beijing 100085, PR China
}

\section{A $R$ T I C L E I N F O}

\section{Article history:}

Received 28 June 2010

Received in revised form

17 February 2011

Accepted 18 February 2011

\section{Keywords:}

Microclimate

Ozone

Sap flux density

Variation partitioning

Hierarchical partitioning

\begin{abstract}
A B S T R A C T
Transpiration rates of six urban tree species in Beijing evaluated by thermal dissipation method for one year were correlated to environmental variables in heat, water, and pollutant groups. To sort out colinearity of the explanatory variables, their individual and joint contributions to variance of tree transpiration were determined by the variation and hierarchical partitioning methods. Majority of the variance in transpiration rates was associated with joint effects of variables in heat and water groups and variance due to individual effects of explanatory group were in comparison small. Atmospheric pollutants exerted only minor effects on tree transpiration. Daily transpiration rate was most affected by air temperature, soil temperature, total radiation, vapor pressure deficit, and ozone. Relative humidity would replace soil temperature when factors influencing hourly transpiration rate was considered.
\end{abstract}

(c) 2011 Elsevier Ltd. All rights reserved.

\section{Introduction}

Trees have profound influences on urban ambience. They modulate temperature and microclimate, buffer airborne pollutions, provide aesthetic surroundings, and so forth (Nowak and Dwyer, 2007). Metropolises around the world expend a great deal of effort to create and maintain urban green spaces. Beijing, the capital of China, has undergone rapid urban renewal and development. The city has a population over 16 million occupying a footprint of $873 \mathrm{~km}^{2}$ (Statistical Yearbook of Beijing, 2008). Approximately 44\% (Statistical Yearbook of Beijing, 2008) of the city is open and green spaces consisting of tree-lined traffic corridors, ornamental landscapes, green belts, regional and neighborhood parks, botanic gardens, woods, and wetlands. Trees are essential components of all urban green spaces. More than 2056 species of vascular plants (He et al., 1993) and over 61 million trees (Beijing Municipal Bureau of Landscape and Forestry, 2005) are planted across the city.

Transpiration is an essential physiological process that would keep the trees vigorous and healthy. It transfers water and mineral nutrients from soils to plants and in summer helps trees to dissipate heat. The process is regulated by a combination of biotic and abiotic forces that need to be evaluated when the performances of trees are considered. Microclimates characterized by solar radiation, wind, vapor pressure deficit, soil water content,

\footnotetext{
* Corresponding author.

E-mail address: zyouyang@rcees.ac.cn (Z. Ouyang).
}

rainfall, and temperature are the main external factors on tree transpiration (Granier et al., 1996; Mellander et al., 2004; Burgess, 2006; Huang et al., 2009). The canopy surface conductance and stand structure would further influence the outcomes (Granier et al., 1996).

Trees grown in urban settings are subject to drastically changing microclimates and are expected to use greater amounts of water than those in the natural settings. Vegetations occupying isolated and small urban spaces such as hedges, garden plants, and roadside trees are exposed to more intense radiation and sensible heat due to a lack of obstacles therefore lose more water than comparable vegetations in the forests (Van Bavel et al., 1962; Hagishima et al., 2007). The pervasive presence of airborne pollutants would be a confounding issue. Evidences obtained through measurements of excised leaves, seedlings, and mature trees showed that water loss of forest trees increased when exposed to air pollutants (Neighbour et al., 1988; Lee et al., 1990; McLaughlin et al., 2007). Air pollution nevertheless is only one of many factors that affect tree transpiration in urban environment. Site design, species selection, and landscape upkeep can affect water consumption (Nowak and Dwyer, 2007).

The environmental factors affecting tree transpiration are interrelated. The environmental effects on tree transpiration when evaluated by the traditional regression techniques (Xia et al., 2008) may have distorted inferences about the relative importance of explanatory variables (Heikkinen et al., 2005). The variation partitioning (Borcard et al., 1992) and hierarchical partitioning methods (MacNally, 1996) may be employed to overcome the complications caused by collinearity of experimental data. They provide 
unambiguous identification of significant variables and understanding of the true interrelationships between tree transpiration and environmental variables.

Variation partitioning decomposes the variance of a dependent variable, i.e. transpiration rate, associated with explanatory variable groups, i.e. heat, water and pollutant, into components of individual effect and joint effects with other variable groups (Borcard et al., 1992; Heikkinen et al., 2004, 2005). It outlines the relative importance of individual and joint contributions of explanatory variable groups toward the variance of a dependent response variable (Borcard et al., 1992). In parallel, hierarchical partitioning utilizes all models in a regression hierarchy to provide estimates of the explanatory capacities of variables in all groups independently and jointly (MacNally, 1996). It may assess the contributions of each explanatory variable to a dependent response variable. For examples, how did environmental variables influence the occupancy and abundance of the clouded Apollo butterfly (Heikkinen et al., 2005), abundance of birds (Heikkinen et al., 2004), and coffee pest densities (Teodoro et al., 2008)? The transpiration of urban tree depends on three interrelated environmental factor groups namely, heat, water and pollutant. The colinearity between the variables in the groups complicates the assessment of environment-induced impacts. Therefore, both variation partitioning and hierarchical partitioning may be used to explore urban tree transpiration-environment relationships.

Transpiration of urban trees is not easy to accurately measure in situ because of large trees, low plant density, diversity of species, and heterogeneity of surface. The water use patterns of potted plants arranged in varying urban landscaping compositions have been investigated (Neighbour et al., 1988; Montague and Kjelgren, 2004; Hagishima et al., 2007). The small potted trees and mature trees in situ are different in energy budgets, canopy/root balance, architecture, and carbon allocation patterns (McLaughlin et al., 2007). The outcomes derived from potted plants or seedlings fail to represent the responses of well established trees inhabiting the urban landscape. Granier (1987) developed a method of measuring xylem sap flow that provided a continuous, accurate, and inexpensive estimate of whole-tree transpiration. It has been used to simultaneously track the transpiration of several species in multilayered urban scene (Costa et al., 2006). Coupled with continuous monitoring environmental parameters at comparable time scales, effects of environmental factors on urban tree transpiration may be delineated.

We hypothesized that sap flux density of urban trees is affected by the interrelated environmental factors that characterize their surroundings. The sap flux densities of six tree species that were common presence in Beijing were assessed with respect to 12 environmental factors divided into three groups i.e. heat energy transfer, water availability, and extent of air pollution. Specifically, we posted the following research questions: (1) Do the outcomes of variation partitioning analysis able to distinguish the relative significance of the three groups of variables to urban tree transpiration?, (2) To what extents the independent and joint contributions of the three groups of variables account for variations in urban tree transpiration?, and (3) Which environmental variables are the most important predictors of urban tree transpiration, including air pollutants effects?

\section{Materials and methods}

\subsection{Study sites and trees}

The study was conducted in the 116,500 $\mathrm{m}^{2}$ Beijing Teaching Botanical Garden, located toward the center of Beijing $\left(116^{\circ} 25^{\prime} 37^{\prime \prime}\right.$ to $116^{\circ} 25^{\prime} 50^{\prime \prime} \mathrm{E}, 39^{\circ} 52^{\prime} 20^{\prime \prime}$ to $39^{\circ} 52^{\prime} 28^{\prime \prime} \mathrm{N}$ ). The City situated in a warm temperate zone and has a typical continental monsoon climate. Mean annual precipitation is about $585.5 \mathrm{~mm}$ with more than $70 \%$ of the annual total occurring from June to August. Mean annual temperature is about $11-12^{\circ} \mathrm{C}$. The experimental site is a typical green space in the city center surrounded by densely populated commercial and residential establishments and amidst heavy pedestrian and motor vehicle traffic.

Four deciduous tree species (Ginkgo biloba, Aesculus chinensis, Magnolia liliiflora, Robinia pseudoacacia) and two evergreen coniferous tree species (Pinus tabulaeformis, Cedrus deodara) were selected as study species. They are common urban tree species in Beijing. The differences of leaf characteristics and life forms among species however were wide, indicative of the diversity of tree species included in the study. For each species, two or three trees of comparable size, in terms of diameter at the breast height, height, projected canopy area, and sapwood cross-sectional area, were randomly selected for sampling (Table 1). As the instrument measured the sap flux density of an individual tree, each tree in fact represented a replicate in the measurements. Anywhere from 1 to 8 individual trees had been chosen for transpiration measurements under various landscape settings (Granier et al., 1996; Pataki and Oren, 2003; Lu et al., 2003; O'Brien et al., 2004; Burgess, 2006; Costa et al., 2006; Fernandez et al., 2009). Two or three selected trees for each species would be adequate to overcome the measurement errors.

\subsection{Environmental variables}

An automated weather station was installed at the experimental site to record continuous changes of environmental parameters. It was located at an open area that was free of influences of trees, buildings, and other obstacles and within short distances of the trees selected for the study. Air temperature $\left(T_{\mathrm{a}}\right)$ and relative humidity (RH) probe (HMP45C, Vaisala Inc., Helsinki, Finland), wind ( $w$ ) sensor (034B, Met One Instruments, Grants Pass, Oregon, USA) were installed at a standard 10 meter mast. A pyranometer (CMP-11, Kipp and Zonen, Delft, Netherlands) was installed at a standard $1.5 \mathrm{~m}$ mast for solar radiation $\left(R_{\mathrm{S}}\right)$ measurement. Precipitation $(P)$ (TE525 MM, Campbell Scientific, Inc., Logan, UT) was measured by pluviometer installed $<2 \mathrm{~m}$ from ground surface. The soil temperature $\left(T_{\mathrm{s}}\right)$ probe was set at the depth of 10, 30, 50, and $80 \mathrm{~cm}$ (109, Campbell Scientific, Inc., Logan, UT). Probes for soil water measurements were spaced in between the sampled trees. Three soil water probes $\left(\mathrm{ECH}_{2} \mathrm{O}\right.$, Decagon Devices, Inc., Pullman, WA, USA) were placed at the depth of $30 \mathrm{~cm}$. Vapor pressure deficit $(D)$ was calculated from the air temperature and relative humidity data (Campbell and Norman, 1998). These meteorological changes were continuously monitored and were synchronized with the sap flow measurements.

Concentrations of nitrogen oxides $\left(\mathrm{NO}-\mathrm{NO}_{2}-\mathrm{NO}_{x}\right)$, sulfur dioxide $\left(\mathrm{SO}_{2}\right)$, ozone $\left(\mathrm{O}_{3}\right)$, and particulate matter with diameters of $2.5 \mu \mathrm{m}$ or less $\left(\mathrm{PM}_{2.5}\right)$ in the ambient air were monitored amongst the trees using TEI Model 42i, 43i, 49i gas analyzers (Thermo Environmental Instruments, Inc., Franklin, MA, USA), and a tapered element oscillating microbalance (TEOM, Series 1400, Rupprecht \& Patashnick Co., Inc., Albany, NY, USA), respectively. The fluctuations of pollutant concentrations were recorded every hour.

Table 1

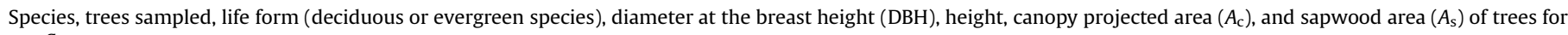
sap flow measurements.

\begin{tabular}{|c|c|c|c|c|c|c|}
\hline Species & Trees sampled & Life form & $\mathrm{DBH}(\mathrm{cm})$ & Height (m) & $A_{\mathrm{c}}\left(\mathrm{m}^{2}\right)$ & $A_{\mathrm{s}}\left(\mathrm{cm}^{2}\right)$ \\
\hline G. biloba & 2 & Deciduous & $16.9 \pm 1.4$ & $6.3 \pm 0.0$ & $16.2 \pm 2.5$ & $105.0 \pm 12.3$ \\
\hline A. chinensis & 3 & Deciduous & $17.3 \pm 0.9$ & $6.4 \pm 0.2$ & $19.0 \pm 1.8$ & $111.4 \pm 2.3$ \\
\hline M. liliiflora & 3 & Deciduous & $8.9 \pm 0.2$ & $3.6 \pm 0.4$ & $2.7 \pm 0.4$ & $48.2 \pm 2.2$ \\
\hline R. pseudoacacia & 3 & Deciduous & $38.4 \pm 2.4$ & $12.9 \pm 0.2$ & $71.9 \pm 10.2$ & $129.1 \pm 12.1$ \\
\hline P. tabulaeformis & 3 & Evergreen & $18.3 \pm 1.0$ & $5.8 \pm 0.1$ & $22.8 \pm 1.2$ & $193.3 \pm 23.1$ \\
\hline C. deodara & 3 & Evergreen & $29 \pm 3.1$ & $8.3 \pm 1.5$ & $39.8 \pm 9.4$ & $408.6 \pm 62.4$ \\
\hline
\end{tabular}

All measurements indicate the mean \pm standard error of sampled trees. 


\subsection{Sap flow measurements}

The transpiration rate was evaluated by sap flow measurements according to Granier (1987). Instantaneous sap flux density, flow per unit sapwood crosssectional area $\left(J_{s}, \mathrm{~g} \mathrm{H}_{2} \mathrm{O} \mathrm{cm} \mathrm{cm}^{-2} \mathrm{~s}^{-1}\right)$, was continuously measured by thermal dissipation probes (Dynamax, Houston, TX, USA), from April 1, 2008 to October 31, 2009. Unlike the intermittent measurements, the continuous recordings capture the entire transpiration process, which are more reliable and less susceptible to measurement errors. Due to the equipment malfunctioning, there were discontinuations in the sap flux recordings. The trends nonetheless were apparent. At the hourly and daily scales, the disruptions statistically did not affect the data analysis. The numbers of sensors deployed was based on the trunk diameter at breast height (DBH). One pair of $30 \mathrm{~mm}$ long probes (TDP 30) was deployed on the north side of each G. biloba, A. chinensis, and M. liliiflora tree whose DBH was around $15 \mathrm{~cm}$. Two pairs of TDP 30 were deployed respectively on north and south sides of each $P$. tabulaeformis tree whose DBH ranged from 15 to $20 \mathrm{~cm}$. Four pairs of TDP 30 were deployed on all four sides of each $R$. pseudoacacia and C. deodara tree whose DBH was larger than $20 \mathrm{~cm}$. For $P$. tabulaeformis and $C$. deodara that had deep sapwood, $80 \mathrm{~mm}$ long probes (TDP 80) were also deployed. The probe consisted of a pair of matching needles, each containing a copper-constantan thermocouple (Granier, 1987). The probe was radially inserted into the sapwood approximately $15 \mathrm{~cm}$ apart. The probes and adjacent portions of stem were wrapped with first a layer of plastic bubble-wrap and then aluminum foil to minimize spurious temperature gradients caused by radiant heating of the stem as well as to protect against water running down the trunk (Zhao et al., 2005). Sap flux density was calculated from the temperature difference using Granier's (1987) empirical relationship:

$J_{\mathrm{s}}=118.99 \times 10^{-4}\left(\frac{\Delta T_{\mathrm{m}}-\Delta T}{\Delta T}\right)^{1.231}$

where $\Delta T_{\mathrm{m}}$ and $\Delta T$ are the temperature differences of heated and unheated needles at no flow and positive xylem flow conditions, respectively. The temperatures were continuously scanned $10 \mathrm{~s}$ interval and the average of every $10 \mathrm{~min}$ was stored in data loggers (CR1000, Campbell Scientific Inc., UK).

The data collected from November 1, 2008 to October 31, 2009 was selected to evaluate how environmental factors affected the transpiration of urban trees for an entire year. To capture the influences of rapidly and widely fluctuating environment on transpiration of urban trees, it was imperative that the tree sap flux be evaluated at both daily and hourly scales.

\subsection{Variation partitioning}

We conducted variation partitioning following Anderson and Cribble (1998), and Heikkinen et al. (2004, 2005). Variation partitioning would partition the variance of sap flux density into eight fractions namely, the individual effects of water, heat, and air pollutant denoted as $a, b$, and $c$, respectively, joint effects of heat and water, water and air pollutant, and heat and air pollutant denoted as $d, e$, and $f$, respectively, joint effects of three explanatory variable groups denoted as $g$, and finally the unexplained variance denoted as $h$.

Firstly, a series of six redundancy analysis (RDA) runs according to a forward selection option in CANOCO and the associated Monte Carlo permutation tests (involving 9999 permutations) were performed for each group to exclude explanatory variables that did not contribute significantly to variance of sap flux density, at $P>0.05$ (Borcard et al., 1992). We also entered the quadratic terms into the RDA forward selection procedure to take into account the potential curvilinear relationships between explanatory variables and sap flux density (Heikkinen et al., 2004). Only the significant environmental variables identified in this process were included in subsequent analyses.

Secondly, the sap flux density was regressed collectively with respect to the three groups that yielded the total explained variation of sap flux density namely $(a+b+c+d+e+f+g)$. Subsequently, regressing sap flux density with each explanatory group separately yielded the variation captured by water $(a+d+e+g)$ heat $(b+d+f+g)$ and air pollutant $(c+e+f+g)$.

Then, six RDA runs were performed to determine the pure fractions of each explanatory group and three groups of fractions showing the joint effects of two of the groups at a time:

- RDA of sap flux density, constrained by the water variables, with heat and air pollutant variables treated as covariables (fraction $a$ );

- RDA of sap flux density, constrained by the heat variables, with water and air pollutant variables treated as covariables (fraction $b$ );

- RDA of sap flux density, constrained by the air pollutant variables, with heat and water variables treated as covariables (fraction $c$ );

- RDA of sap flux density, constrained by water and, heat variables with air pollutant variables treated as covariables (fractions $a+b+d$ );

- RDA of sap flux density, constrained by heat and air pollutant variables, with water variables treated as covariables (fractions $b+c+f$ );

- RDA of sap flux density, constrained by water and air pollutant variables, with heat as covariables (fractions $a+c+e$ ).
Finally, the remaining variation components were calculated using two sets of equations:

$d+e+g=$ Water $-a$

$d+f+g=$ Heat $-b$

$e+f+g=$ Pollutant $-c$

and

$d=(a+b+d)-(a+b)$

$e=(a+c+e)-(a+c)$

$f=(b+c+f)-(b+c)$

$g=(d+e+g)-d-e=(d+f+g)-d-f=(e+f+g)-e-f$

where Water, Heat, and Pollutant denote variances due to the water variables $(D, \mathrm{RH}$, and $\left.S W C_{30}\right)$, heat variables $\left(T_{\mathrm{a}}, T_{\mathrm{s} 10}\right.$, and $\left.R_{\mathrm{s}}\right)$, and pollutant variables $\left(\mathrm{NO}_{2}, \mathrm{O}_{3}, \mathrm{SO}_{2}\right.$, and $\mathrm{PM}_{2.5}$ ), respectively. In this manner, the relative contribution due to each fraction may be obtained by solving equations simultaneously.

\subsection{Hierarchical partitioning}

The hierarchical partitioning method was used to identify the individual variable that significantly affected the transpiration of urban tree. This method was accomplished using the 'hier.part package' version 0.5-1 (Walsh and MacNally, 2003) that was a part of the $R$ statistical package. The maximum number of predictor variables that can be entered in this partition routine is 12 (Heikkinen et al., 2004) and we included 10 related variables. Hierarchical partitioning depends on monotonic relationships between the response and predictor variables (Heikkinen et al., 2004). Hence, the vapor pressure deficit data was log transformed to improve the linearity of relationships between it and sap flux density.

\section{Results}

\subsection{Urban environmental conditions and sap flux during the study period}

The heat, water, and pollutant groups of variables showed temporal fluctuations (Fig. 1, Table 2). The total radiation $\left(R_{\mathrm{S}}\right)$, air temperature $\left(T_{\mathrm{a}}\right)$, and soil temperature $\left(T_{\mathrm{s} 10}\right)$ exhibited similar seasonal trends. Their magnitudes were lower in the winter months of November through February and gradually rose to the maximal in summer months of June and July. They displayed wide fluctuations, especially $R_{\mathrm{S}}$ and especially in the summer months. Air temperature, and therefore vapor pressure deficit $(D)$, showed a similar seasonal trend, while no pattern in atmospheric relative humidity $(\mathrm{RH})$ was apparent. The soil water content $\left(\mathrm{SWC}_{30}\right)$ fluctuated more during the growing season in response to the transpiration demand, water inputs from precipitation $(P)$.

The atmospheric $\mathrm{SO}_{2}, \mathrm{NO}, \mathrm{NO}_{2}$, and $\mathrm{PM}_{2.5}$ concentrations were higher and fluctuated more widely in winter than in summer months. The atmospheric $\mathrm{O}_{3}$ concentration showed an opposite pattern (Fig. 1). During our study period, the mean hourly atmospheric $\mathrm{O}_{3}$ concentration was $22.11 \mathrm{ppb}$, with the maximum reached $138 \mathrm{ppb}$. However, $83.8 \%$ of the hourly atmospheric $\mathrm{O}_{3}$ concentrations were between 0 to $40 \mathrm{ppb}$, and only $7 \%$ of the hourly atmospheric $\mathrm{O}_{3}$ concentrations exceeded $60 \mathrm{ppb}$. The AOT40 (accumulated exposure over a threshold of $40 \mathrm{ppb}$ or $\mathrm{nl}^{-1}$ ) during the growing season at our study site was $20.12 \mathrm{ppm} \mathrm{h}$.

The $A$. chinesis and $P$. tabulaeformis exhibited the highest mean daily sap flux density $\left(J_{s}\right)$ at 120 to $140 \mathrm{~g} \mathrm{H}_{2} \mathrm{O} \mathrm{cm}^{-2} \mathrm{~d}^{-1}$. They were followed by G. biloba, $M$. liliflora, and C. deodara showing daily $J_{S}$ of 100 to $120 \mathrm{~g} \mathrm{H}_{2} \mathrm{O} \mathrm{cm}^{-2} \mathrm{~d}^{-1}$, and then $R$. pseudoacacia showing daily $J_{s}$ of $<100 \mathrm{~g} \mathrm{H}_{2} \mathrm{O} \mathrm{cm}^{-2} \mathrm{~d}^{-1}$ (Table 3 ). The daily $J_{s}$ showed a seasonal change pattern that was interlaced with daily fluctuations, especially in the summer months (Fig. 2). During the winter months, even the daily $J_{s}$ of evergreen trees was markedly dampened (Fig. 2). 


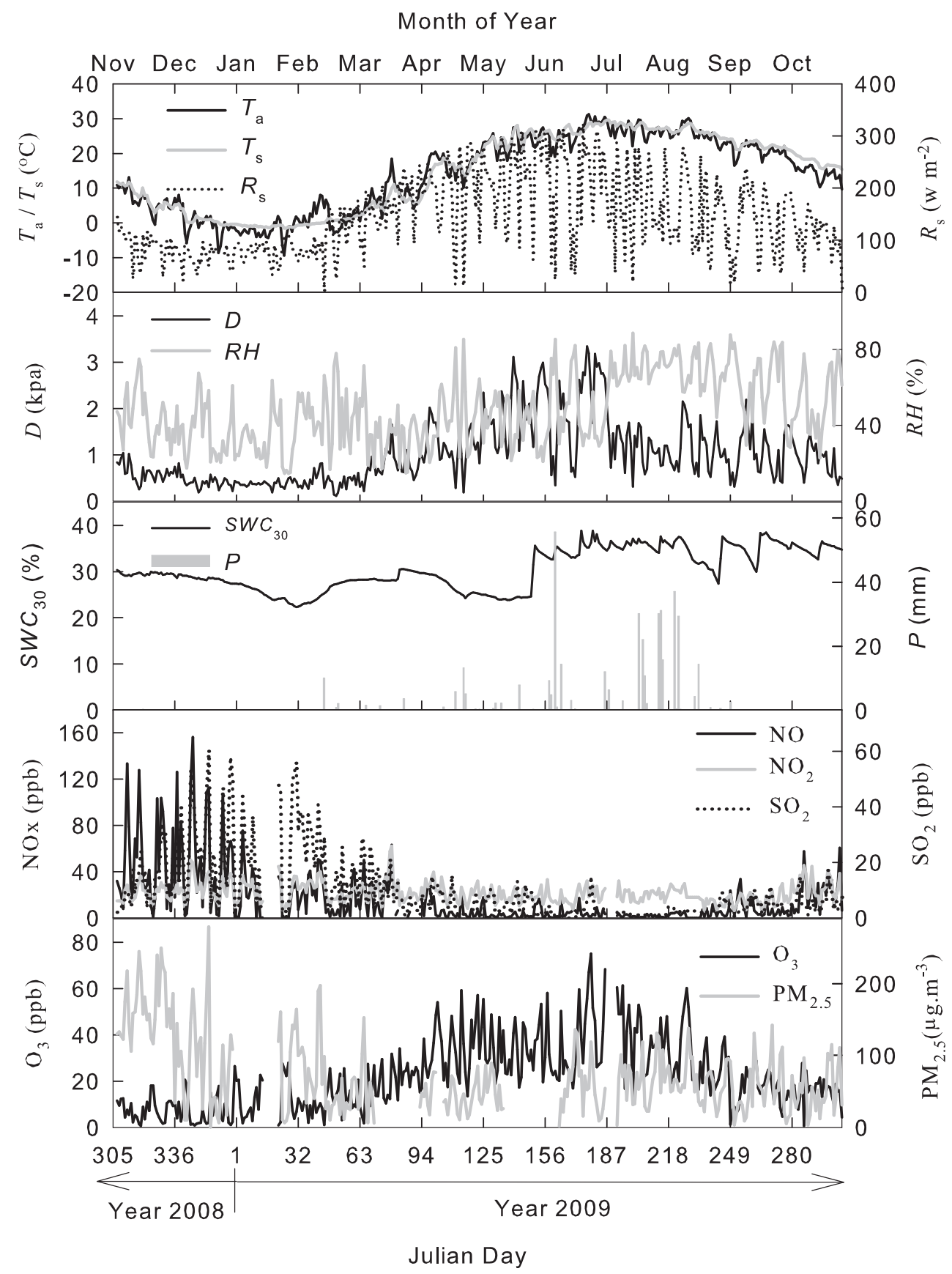

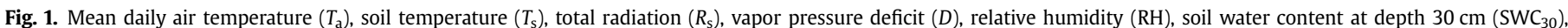

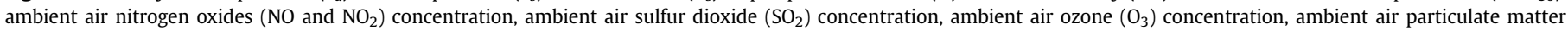
$\left(\mathrm{PM}_{2.5}\right)$ concentration, and daily sums of precipitation $(P)$ from November 1, 2008 (Julian day 305) to October 30, 2009 (Julian day 304$)$.

\subsection{The relation between urban tree transpiration and environmental variables}

The forward selection process identified explanatory variables that exhibited significant effects on variances of mean daily and hourly transpiration rate of trees under the urban settings (Tables 4 and 5). Variables related to heat energy, water availability, and air quality of the surrounding environment all influenced the transpiration rates of urban trees. However, not the impact of every explanatory variable was significant (Tables 4 and 5). Precipitation and atmospheric NO concentration did not appear to significantly affect the transpiration rates of tree species tested. Precipitation is episodic and does not routinely take place on hourly or daily base throughout the year. It represents a seasonally distributed water inputs, which is more likely to be a constant rather than a variable. Atmospheric NO is a transitory air pollutant that undergoes rapid photochemical oxidation to $\mathrm{NO}_{2}$ and subsequently $\mathrm{O}_{3}$ during summer. During the winter when NO concentration was high, the trees were dormant or the least active and their transpiration rates did not respond much to the environmental changes.

For remaining variables, the linear and quadratic effects were equally strong (Tables 4 and 5). The quadratic effects of the explanatory variables are especially apparent on the hourly transpiration rates of trees (Table 5). It was applicable to almost all the 
Table 2

Descriptive statistics of mean daily urban environmental factors from November 1, 2008 to October 30, 2009.

\begin{tabular}{|c|c|c|c|c|c|c|c|}
\hline Variable & & Unit & $n^{\mathrm{a}}$ & Minimum & Maximum & Mean & Median \\
\hline \multirow[t]{3}{*}{ Heat Group } & Air temperature & ${ }^{\circ} \mathrm{C}$ & 366 & -9.36 & 31.18 & 13.95 & 15.53 \\
\hline & Soil temperature & ${ }^{\circ} \mathrm{C}$ & 366 & -1.55 & 29.57 & 14.55 & 16.86 \\
\hline & Total radiation & $\mathrm{W} \mathrm{m}^{-2}$ & 366 & 1.76 & 322.82 & 144.17 & 123.96 \\
\hline \multirow[t]{4}{*}{ Water Group } & Vapor pressure deficit & kpa & 366 & 0.11 & 3.34 & 1.00 & 0.82 \\
\hline & Air relative humidity & $\%$ & 366 & 14.55 & 88.49 & 48.38 & 46.06 \\
\hline & Soil water content & $\%$ & 366 & 22.32 & 38.76 & 30.40 & 29.50 \\
\hline & Precipitation & $\mathrm{mm}$ & 366 & 0.00 & 55.60 & 1.10 & 0.00 \\
\hline \multirow[t]{5}{*}{ Pollutant Group } & Nitrogen monoxide & $\mathrm{ppb}$ & 345 & 0.00 & 156.25 & 16.80 & 5.83 \\
\hline & Nitrogen dioxide & $\mathrm{ppb}$ & 354 & 5.15 & 62.13 & 21.54 & 20.07 \\
\hline & Ozone & $\mathrm{ppb}$ & 354 & 0.70 & 74.86 & 21.93 & 19.69 \\
\hline & Sulfur dioxide & ppb & 352 & 0.00 & 60.31 & 9.76 & 4.64 \\
\hline & Particulate matter & $\mu \mathrm{g} \mathrm{m}^{-3}$ & 287 & 0.43 & 279.16 & 71.78 & 57.83 \\
\hline
\end{tabular}

${ }^{a}$ Effective days during the one year measurement.

heat and water variables and to all the tree species examined. Within each explanatory group, effects of the variables showed parallel patterns. It was an indication that explanatory variables in a group might be interrelated and the variance of tree transpiration rate observed represented the collective contributions.

\subsection{Variation partitioning analyses on urban tree transpiration}

\subsubsection{Water, heat, and pollutants effects on daily transpiration rate}

When the variance of daily transpiration rate across all six species were decomposed, the heat variables $\left(T_{\mathrm{a}}, T_{\mathrm{s} 10}\right.$, and $\left.R_{\mathrm{s}}\right)$ accounted for an average \pm standard error of $64.9 \pm 7.0 \%$ of the variance; the water variables $\left(D, \mathrm{RH}\right.$, and $\left.\mathrm{SWC}_{30}\right)$ accounted for an average \pm standard error of $75.2 \pm 4.7 \%$ of the variance; the air pollutant variables $\left(\mathrm{NO}_{2}, \mathrm{O}_{3}, \mathrm{SO}_{2}\right.$, and $\left.\mathrm{PM}_{2.5}\right)$ accounted for an average \pm standard error of $42.4 \pm 4.8 \%$ of the variance. The amount of variation captured by all of selected explanatory variables collectively was $77.6 \pm 4.6 \%$, average \pm standard error (Table 6 ).

The environmental conditions characterized by the water and heat variables in this case had the primary influences on transpiration rate as always the case in natural ecosystems. The three groups of explanatory variables combined effect, fraction $g$, accounted for the largest portion of variance of daily tree transpiration rates, except for $R$. pseudoacacia, varied between species from 33.3 to $60.3 \%$ (Table 6 ). For the two factor combinations, the combined effects of heat and water variables fraction $d$, are notable, varied between species from 20.2 to $27.3 \%$. The combined effects of water and pollutant variables, fraction $e$, and heat and pollutant variables, fraction $f$, however were relatively minor, varied between species from $<0.1$ to 3.1 and $<0.1$ to $1.1 \%$, respectively. The combination of three groups of explanatory variables plays a more significant role than the same factors individually on daily transpiration rate of trees in urban settings. Individual effects of each variable group on daily transpiration rate, namely fractions $a, b$, and

\section{Table 3}

Descriptive statistics on mean daily sap flux density $\left(\mathrm{g} \mathrm{H}_{2} \mathrm{O} \mathrm{cm}^{-2} \mathrm{~d}^{-1}\right)$ for six species of trees in urban Beijing, from November 1, 2008 to October 30, 2009.

\begin{tabular}{llllrr}
\hline Species & $n^{\mathrm{a}}$ & Minimum & Maximum & Mean & Median \\
\hline G. biloba & 345 & 5.27 & 407.69 & 121.49 & 96.27 \\
A. chinensis & 342 & 1.80 & 408.16 & 137.59 & 100.72 \\
M. liliiflora & 342 & 6.95 & 300.21 & 107.73 & 83.98 \\
R. pseudoacacia & 221 & 3.35 & 307.36 & 88.47 & 80.42 \\
P. tabulaeformis & 305 & 1.39 & 314.02 & 140.77 & 156.62 \\
C. deodara & 292 & 0.83 & 260.51 & 117.65 & 123.18 \\
\hline
\end{tabular}

${ }^{\mathrm{a}}$ Effective days during the one year measurement. c, were relatively minor varying between species from $1.7 \%$ to $5.9 \%$, $0.4 \%$ to $2.8 \%$, and $0.2 \%$ to $2.0 \%$.

For $R$. pseudoacacia, the three groups of explanatory variables combined contribution, fraction $g(22.9 \%)$, was second to water variables, fraction $a(48 \%)$. As precipitation had been excluded in the data analysis, the water variables included $D, \mathrm{RH}$, and $\mathrm{SWC}_{30}$ that were driving forces of and all exert strong quadratic effects on the daily transpiration rate of trees. The morphology of $R$. pseudoacacia, a tall tree with tiny leaves and large canopy, might have influenced the outcomes.

\subsubsection{Water, heat, and pollutants effects on hourly transpiration rate}

When the variances of hourly transpiration rate were decomposed, the heat, water, and pollutant variables accounted for across all six species an average \pm standard error of $58.6 \pm 5.7 \%$, $51.7 \pm 3.0 \%$, and $22.0 \pm 2.6 \%$ of the total variances, respectively (Table 7). The amount of variation captured by all of selected explanatory variables collectively was an average \pm standard error of $67.5 \pm 3.4 \%$.

The heat variables by themselves, fraction $b$, in combination with water variables, fraction $d$, and in combination with water and pollutant variables, fraction $g$, depending on the species accounted for 9.3 to $15.6 \%, 10.3$ to $31.3 \%$, and 12.9 to $28.7 \%$ of the total variance, respectively (Table 7 ). At the hourly scale, contributions of three groups of explanatory variables, fraction $g$, became less apparent than the contributions of water and heat variables, fraction $d$, which exerted the most significant contribution on hourly transpiration rate of urban trees. The patterns displayed by the hourly transpiration rate of the trees are essentially the same as those of the daily transpiration rate (Table 7). For example, effects of pollutant variables by themselves, fraction $c$, and the two factor combination effects involving the pollutant variables, fractions $e$ and $f$, exert relatively minor influences on the hourly tree transpiration rates. Again, water variables, fraction $a$, had considerably greater effects on the hourly transpiration rate of R. pseudoacacia, $29.4 \%$, than on that of other species we tested, varied from 3.3 to $4.0 \%$.

\subsection{Hierarchical partitioning analyses on urban tree transpiration}

The effects of explanatory variables air temperature $\left(T_{\mathrm{a}}\right)$, soil temperature $\left(T_{\mathrm{s} 10}\right)$, total radiation $\left(R_{\mathrm{S}}\right)$, vapor pressure deficit $(D)$, and ozone $\left(\mathrm{O}_{3}\right)$ were significant for the daily transpiration rate of all tree species tested (Fig. 3). The other variables, relative humidity $(\mathrm{RH})$ and soil water content $\left(\mathrm{SWC}_{30}\right)$ were significant contributors to some but not all tree species tested. Atmospheric $\mathrm{NO}_{2}, \mathrm{SO}_{2}$ and 


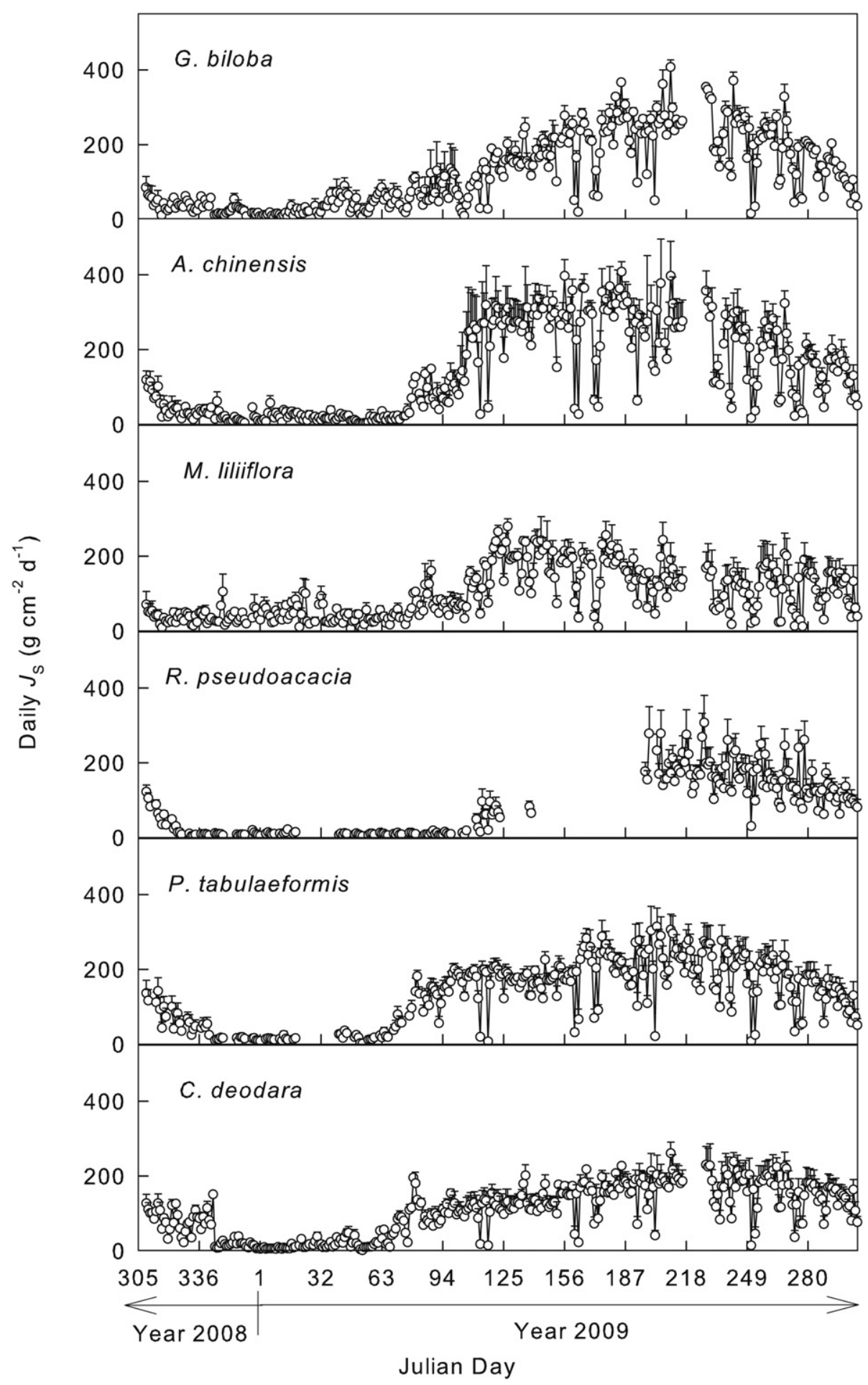

Fig. 2. Daily sap flux density $\left(\sum J_{s}\right)$ for each species \pm SE from November 2008 to October 2009. Days of missing data appear as a result of lightening-induced equipment failure or power-off.

$\mathrm{PM}_{2.5}$ were essentially not contributing to the transpiration rate of trees. Variances of the averaged hourly tree transpiration rate were due essentially to the same environmental variables as those of the daily transpiration rates except that atmospheric relative humidity $(\mathrm{RH})$ replaced soil temperature $\left(T_{\mathrm{s} 10}\right)$ as a significant factor (Fig. 4$)$. Again, the joint contributions of the explanatory variables were more significant than independent effects of the environmental variables (Figs. 3 and 4).

\section{Discussion}

The mean daily sap flux density of the study tree species varied from 88 to $141 \mathrm{~g} \mathrm{H}_{2} \mathrm{O} \mathrm{cm} \mathrm{cm}^{-2} \mathrm{~d}^{-1}$ (Table 3). Measured under comparable conditions, the sap flux densities of $P$. tabulaeformis and $R$. pseudoacacia grown in the urban center were considerably higher than those growing in the surrounding suburban Beijing where trees grown in natural forest settings (Ma et al., 2006; 
Table 4

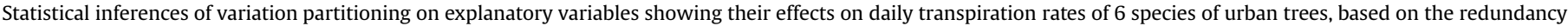
analysis.

\begin{tabular}{|c|c|c|c|c|c|c|c|}
\hline Explanatory variable & & G. biloba & A. chinensis & M. liliiflora & R. pseudoacacia & P. tabulaeformis & C. deodara \\
\hline \multirow[t]{3}{*}{ Heat Group } & Air temperature & $\mathrm{Q}^{* * *}$ & $\mathrm{~L}^{* * *}$ & $\mathrm{~L}^{* * *}+\mathrm{Q}^{*}$ & NS & $\mathrm{L}^{* * *}$ & $\mathrm{~L}^{* * *}+\mathrm{Q}^{* *}$ \\
\hline & Soil temperature & $\mathrm{L}^{*}+\mathrm{Q}^{* * *}$ & $\mathrm{~L}^{* * *}$ & NS & $\mathrm{L}^{* * *}$ & $\mathrm{~L}^{* * *}$ & $\mathrm{~L}^{* *}$ \\
\hline & Total radiation & $\mathrm{L}^{* * *}+\mathrm{Q}^{* * *}$ & $\mathrm{~L}^{* * *}$ & $\mathrm{~L}^{* * *}+\mathrm{Q}^{*}$ & $\mathrm{~L}^{* * *}+\mathrm{Q}^{* * *}$ & $\mathrm{~L}^{* * *}+\mathrm{Q}^{* * *}$ & $\mathrm{~L}^{* *}+\mathrm{Q}^{* * *}$ \\
\hline \multirow[t]{4}{*}{ Water Group } & Vapor pressure deficit & $\mathrm{L}^{* * *}+\mathrm{Q}^{* * *}$ & $\mathrm{~L}^{* * *}+\mathrm{Q}^{* * *}$ & $\mathrm{~L}^{* * *}+\mathrm{Q}^{* * *}$ & $\mathrm{Q}^{* * *}$ & $\mathrm{~L}^{* * *}+\mathrm{Q}^{* * *}$ & $\mathrm{~L}^{* * *}+\mathrm{Q}^{* * *}$ \\
\hline & Air relative humidity & $\mathrm{L}^{* * *}$ & $\mathrm{~L}^{* * *}$ & $\mathrm{~L}^{* *}$ & $\mathrm{~L}^{* * *}+\mathrm{Q}^{* *}$ & $\mathrm{~L}^{*}+\mathrm{Q}^{* *}$ & $\mathrm{Q}^{* * *}$ \\
\hline & Soil water content & $\mathrm{L}^{*}$ & $\mathrm{~L}^{* * *}$ & $\mathrm{~L}^{*}$ & $\mathrm{~L}^{* * *}+\mathrm{Q}^{* * *}$ & $\mathrm{~L}^{* * *}+\mathrm{Q}^{* * *}$ & $\mathrm{Q}^{* * *}$ \\
\hline & Precipitation & NS & NS & NS & NS & NS & NS \\
\hline \multirow[t]{5}{*}{ Pollutant Group } & Nitrogen monoxide & NS & NS & NS & NS & NS & NS \\
\hline & Nitrogen dioxide & NS & NS & $\mathrm{L}^{* *}$ & NS & $\mathrm{L}^{* * *}$ & NS \\
\hline & Ozone & $\mathrm{L}^{* * *}$ & $\mathrm{~L}^{* * *}$ & $\mathrm{~L}^{* * *}$ & $\mathrm{~L}^{*}$ & $\mathrm{~L}^{* * *}$ & $\mathrm{~L}^{* * *}$ \\
\hline & Sulfur dioxide & $\mathrm{L}^{* * *}+\mathrm{Q}^{* * *}$ & $\mathrm{~L}^{* * *}+\mathrm{Q}^{* * *}$ & $\mathrm{Q}^{* * *}$ & $\mathrm{~L}^{* * *}+\mathrm{Q}^{* * *}$ & $\mathrm{~L}^{* * *}+\mathrm{Q}^{* * *}$ & $\mathrm{~L}^{* * *}+\mathrm{Q}^{* * *}$ \\
\hline & Particulate matter & $\mathrm{L}^{*}+\mathrm{Q}^{*}$ & NS & NS & $\mathrm{L}^{* * *}+\mathrm{Q}^{* * *}$ & $\mathrm{~L}^{* *}+\mathrm{Q}^{* *}$ & $\mathrm{~L}^{* *}$ \\
\hline
\end{tabular}

Symbols NS denotes variable not selected during the process.

$\mathrm{L}$ and $\mathrm{Q}$ denote linear and quadratic terms, respectively.

“*”, “***, and “***” indicate inferences are significant at $p<0.05, p<0.01, p<0.001$.

Table 5

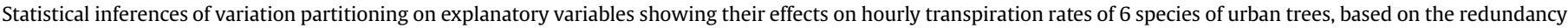
analysis.

\begin{tabular}{|c|c|c|c|c|c|c|c|}
\hline Explanatory variable & & G. biloba & A. chinensis & M. liliiflora & R. pseudoacacia & P. tabulaeformis & C. deodara \\
\hline \multirow[t]{3}{*}{ Heat Group } & Air temperature & $\mathrm{L}^{* * *}+\mathrm{Q}^{* * *}$ & $\mathrm{~L}^{* * *}+\mathrm{Q}^{* * *}$ & $\mathrm{~L}^{* * *}+\mathrm{Q}^{* * *}$ & $\mathrm{~L}^{* * *}+\mathrm{Q}^{* * *}$ & $\mathrm{~L}^{* * *}+\mathrm{Q}^{* * *}$ & $\mathrm{~L}^{* * *}+\mathrm{Q}^{* * *}$ \\
\hline & Soil temperature & $\mathrm{L}^{* * *}+\mathrm{Q}^{* * *}$ & $\mathrm{~L}^{* * * *}+\mathrm{Q}^{* * *}$ & $\mathrm{~L}^{* * *}+\mathrm{Q}^{* * *}$ & $\mathrm{~L}^{* * *}+\mathrm{Q}^{* * *}$ & $\mathrm{~L}^{* * *}+\mathrm{Q}^{* * *}$ & $\mathrm{~L}^{* * *}+\mathrm{Q}^{* * *}$ \\
\hline & Total radiation & $\mathrm{L}^{* * *}+\mathrm{Q}^{* * *}$ & $\mathrm{~L}^{* * *}$ & $\mathrm{~L}^{* * *}+\mathrm{Q}^{* * *}$ & $\mathrm{~L}^{* * *}+\mathrm{Q}^{* * *}$ & $\mathrm{~L}^{* * *}+\mathrm{Q}^{* * *}$ & $\mathrm{~L}^{* * *}+\mathrm{Q}^{* * *}$ \\
\hline \multirow[t]{4}{*}{ Water Group } & Vapor pressure deficit & $\mathrm{L}^{* * *}+\mathrm{Q}^{* * *}$ & $\mathrm{~L}^{* * *}+\mathrm{Q}^{* * *}$ & $\mathrm{~L}^{* * *}+\mathrm{Q}^{* * *}$ & $\mathrm{~L}^{* * *}+\mathrm{Q}^{* * *}$ & $\mathrm{~L}^{* * *}+\mathrm{Q}^{* * *}$ & $\mathrm{~L}^{* * *}+\mathrm{Q}^{* * *}$ \\
\hline & Air relative humidity & $\mathrm{L}^{* * *}+\mathrm{Q}^{* * *}$ & $\mathrm{~L}^{* * *}+\mathrm{Q}^{* * *}$ & $\mathrm{~L}^{* * *}+\mathrm{Q}^{* *}$ & $\mathrm{~L}^{* * *}+\mathrm{Q}^{* * *}$ & $\mathrm{~L}^{* * *}+\mathrm{Q}^{* * *}$ & $\mathrm{~L}^{* * *}$ \\
\hline & Soil water content & $\mathrm{L}^{* * *}+\mathrm{Q}^{* * *}$ & $\mathrm{~L}^{* * * *}+\mathrm{Q}^{* * *}$ & $\mathrm{~L}^{* * *}+\mathrm{Q}^{* * *}$ & $\mathrm{~L}^{* * *}+\mathrm{Q}^{* * *}$ & $\mathrm{~L}^{* * *}+\mathrm{Q}^{* * *}$ & $\mathrm{~L}^{* * *}$ \\
\hline & Precipitation & NS & NS & NS & NS & NS & NS \\
\hline \multirow[t]{5}{*}{ Pollutant Group } & Nitrogen monoxide & NS & NS & NS & NS & NS & $\mathrm{L}^{* *}+\mathrm{Q}^{* * *}$ \\
\hline & Nitrogen dioxide & $\mathrm{L}^{* * *}+\mathrm{Q}^{* * *}$ & $\mathrm{~L}^{* * *}+\mathrm{Q}^{* * *}$ & $\mathrm{~L}^{* * *}+\mathrm{Q}^{* * *}$ & $\mathrm{~L}^{* * *}+\mathrm{Q}^{* * *}$ & $\mathrm{~L}^{* * *}+\mathrm{Q}^{* * *}$ & $\mathrm{~L}^{* * *}+\mathrm{Q}^{* * *}$ \\
\hline & Ozone & $\mathrm{L}^{* * *}$ & $\mathrm{~L}^{* * *}$ & $\mathrm{~L}^{* * *}$ & $\mathrm{~L}^{* * *}+\mathrm{Q}^{* *}$ & $\mathrm{~L}^{* * *}+\mathrm{Q}^{* * *}$ & $\mathrm{~L}^{* * *}+\mathrm{Q}^{* * *}$ \\
\hline & Sulfur dioxide & NS & NS & $\mathrm{L}^{* * *}$ & $\mathrm{~L}^{* *}$ & $\mathrm{~L}^{* *}$ & NS \\
\hline & Particulate matter & $\mathrm{L}^{* * *}+\mathrm{Q}^{* * *}$ & $\mathrm{~L}^{* *}+\mathrm{Q}^{* *}$ & NS & $\mathrm{L}^{* * *}+\mathrm{Q}^{* *}$ & $\mathrm{~L}^{* * *}+\mathrm{Q}^{* * *}$ & $\mathrm{~L}^{* * *}+\mathrm{Q}^{* * *}$ \\
\hline
\end{tabular}

Symbols NS denotes variable not selected during the process.

$\mathrm{L}$ and $\mathrm{Q}$ denote linear and quadratic terms, respectively.

** and ${ }^{* * *}$ indicate inferences are significant at $p<0.01$ and $p<0.001$, respectively.

Fan et al., 2008). The significant increment of tree transpiration in the urban area may be attributable to the higher air temperatures (Wang et al., 2005; Xiao et al., 2007) and lower plant density (Hagishima et al., 2007) in urban than suburban Beijing.

Strong seasonality in daily sap flux density was observed during the study period (Fig. 1). In this regard, it would be appropriate to relate the transpiration rates of urban trees to the seasonally changing environmental variable groups of heat energy, water availability and atmospheric pollutants that by themselves interrelated. The high daily sap flux density in summer coincides with the season of rapid growth, ample supply of water, and strong solar radiation, typical environment of trees in temperate and tropical ecosystems (Zeppel et al., 2006). The heat $\left(T_{\mathrm{a}}, T_{\mathrm{s} 10}\right.$, and $\left.R_{\mathrm{s}}\right)$, water
$\left(D, \mathrm{RH}\right.$, and $\left.\mathrm{SWC}_{30}\right)$, and pollutant variables $\left(\mathrm{NO}_{2}, \mathrm{O}_{3}, \mathrm{SO}_{2}\right.$, and $\mathrm{PM}_{2.5}$ ) significantly affected the transpiration of urban tree over one year (Tables 4 and 5). The heat variables had the largest influence on hourly transpiration rates of trees (Table 7), as the stomata of trees would be sensitive to intensity changes of solar radiation. It also suggested that heat variables would determine the shape of the diurnal sap flux of trees. The water variables exerted the largest influence on the daily tree transpiration (Table 6). The water variables, vapor pressure deficit and relative humidity, were secondary environmental factors because their changes were induced by changes in total radiation and ambient temperature and exhibited delays in responses. Along with the soil water content, they control the amount of total water available for uptake by trees. Other

Table 6

Relative effects of water, heat, and pollutant variables on daily tree transpiration rates.

\begin{tabular}{|c|c|c|c|c|c|c|c|c|}
\hline Species & $\begin{array}{l}\text { Water } \\
\text { (a) }\end{array}$ & $\begin{array}{l}\text { Heat } \\
(b)\end{array}$ & $\begin{array}{l}\text { Pollutant } \\
(c)\end{array}$ & $\begin{array}{l}\text { Water } \times \text { Heat } \\
(d)\end{array}$ & $\begin{array}{l}\text { Water } \times \text { Pollutant } \\
(e)\end{array}$ & $\begin{array}{l}\text { Heat } \times \text { Pollutant } \\
(f)\end{array}$ & $\begin{array}{l}\text { Water } \times \text { Heat } \times \text { Pollutant } \\
(g)\end{array}$ & Unaccounted \\
\hline G. biloba & $1.7 \%$ & $1.9 \%$ & $0.5 \%$ & $24.5 \%$ & NS & $0.5 \%$ & $40.70 \%$ & $30.3 \%$ \\
\hline A. chinenses & $5.9 \%$ & $2.8 \%$ & $0.2 \%$ & $20.2 \%$ & $0.6 \%$ & $1.1 \%$ & $45.30 \%$ & $23.9 \%$ \\
\hline M. liliflora & $5.7 \%$ & $0.4 \%$ & $2 \%$ & $23 \%$ & NS & NS & $33.3 \%$ & $36.1 \%$ \\
\hline R. pseudoacacia & $48 \%$ & $0.8 \%$ & $0.4 \%$ & $12.5 \%$ & $3.1 \%$ & $0.4 \%$ & $22.9 \%$ & $11.9 \%$ \\
\hline P. tabulaeformis & $4.7 \%$ & $1.2 \%$ & $0.4 \%$ & $26.6 \%$ & $0.2 \%$ & $0 \%$ & $60.3 \%$ & $6.6 \%$ \\
\hline C. dedodara & $2.7 \%$ & $1.7 \%$ & $0.3 \%$ & $27.3 \%$ & NS & $0.2 \%$ & $42.3 \%$ & $25.6 \%$ \\
\hline
\end{tabular}

Symbols NS denotes no effects. 
Table 7

Relative effects of water, heat, and pollutant variables on hourly tree transpiration rates.

\begin{tabular}{|c|c|c|c|c|c|c|c|c|}
\hline Species & $\begin{array}{l}\text { Water } \\
(a)\end{array}$ & $\begin{array}{l}\text { Heat } \\
(b)\end{array}$ & $\begin{array}{l}\text { Pollutant } \\
\text { (c) }\end{array}$ & $\begin{array}{l}\text { Water } \times \text { Heat } \\
(d)\end{array}$ & $\begin{array}{l}\text { Water } \times \text { Pollutant } \\
(e)\end{array}$ & $\begin{array}{l}\text { Heat } \times \text { Pollutant } \\
(f)\end{array}$ & $\begin{array}{l}\text { Water } \times \text { Heat } \times \text { Pollutant } \\
(g)\end{array}$ & Unaccounted \\
\hline G. biloba & $3.5 \%$ & $11.5 \%$ & $0.6 \%$ & $24.3 \%$ & NS & $1.9 \%$ & $18.8 \%$ & $39.6 \%$ \\
\hline A. chinenses & $3.6 \%$ & $12.5 \%$ & $0.4 \%$ & $31.3 \%$ & NS & $1.1 \%$ & $19.7 \%$ & $31.7 \%$ \\
\hline M. liliflora & $3.3 \%$ & $14.3 \%$ & $0.9 \%$ & $26.3 \%$ & NS & $1.2 \%$ & $12.9 \%$ & $41.3 \%$ \\
\hline R. pseudoacacia & $29.4 \%$ & $9.3 \%$ & $1.8 \%$ & $10.3 \%$ & $0.3 \%$ & $1.8 \%$ & $13.5 \%$ & $33.6 \%$ \\
\hline P. tabulaeformis & $4 \%$ & $15.6 \%$ & $0.9 \%$ & $29.9 \%$ & $0.7 \%$ & $2.5 \%$ & $28.7 \%$ & $17.7 \%$ \\
\hline C. dedodara & $3.8 \%$ & $15.5 \%$ & $0.7 \%$ & $24.6 \%$ & $0.1 \%$ & $2.4 \%$ & $21.9 \%$ & $31 \%$ \\
\hline
\end{tabular}

Symbols NS denotes no effects.
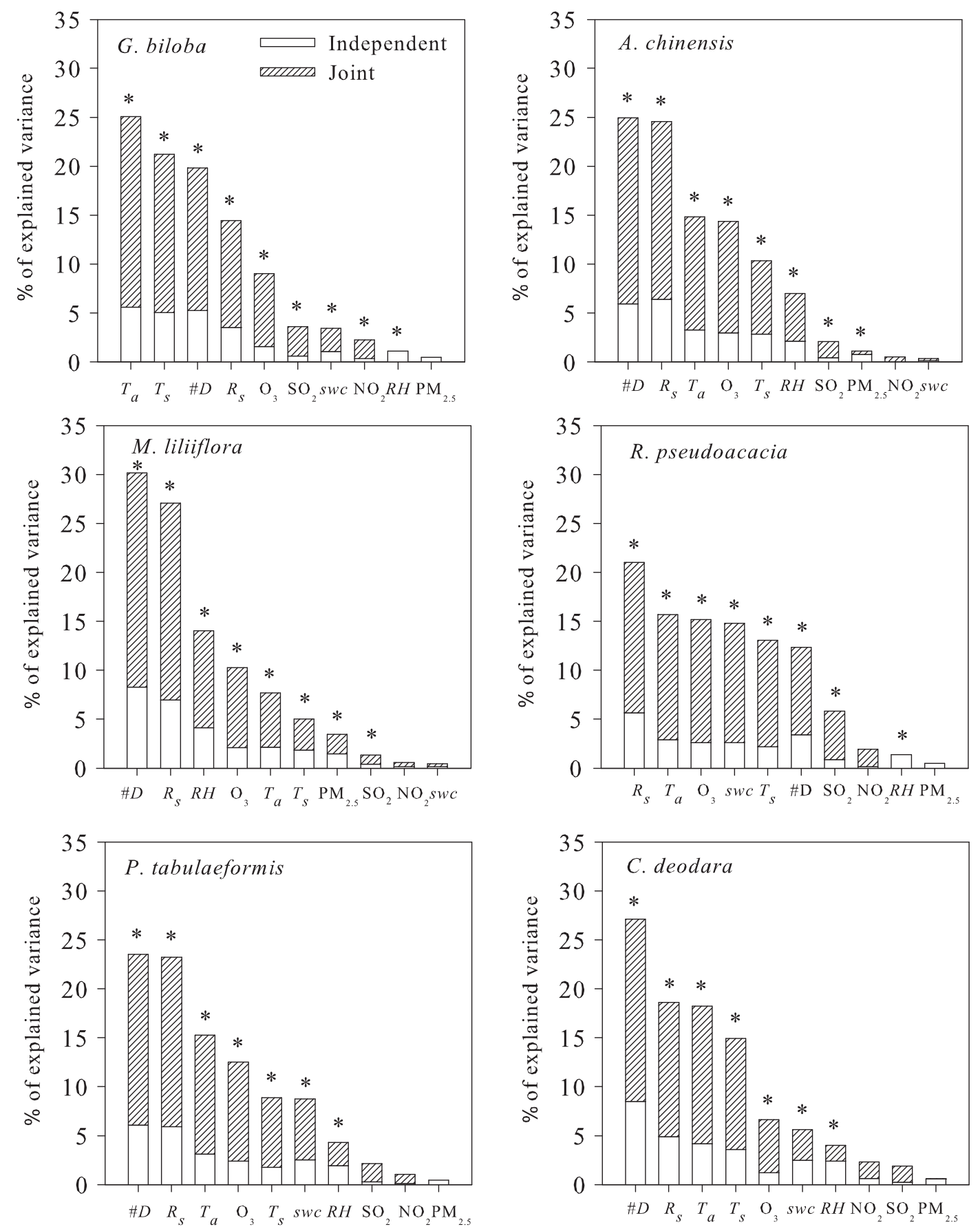

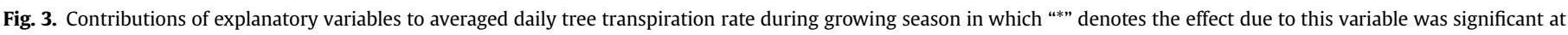
$p<0.05$. 

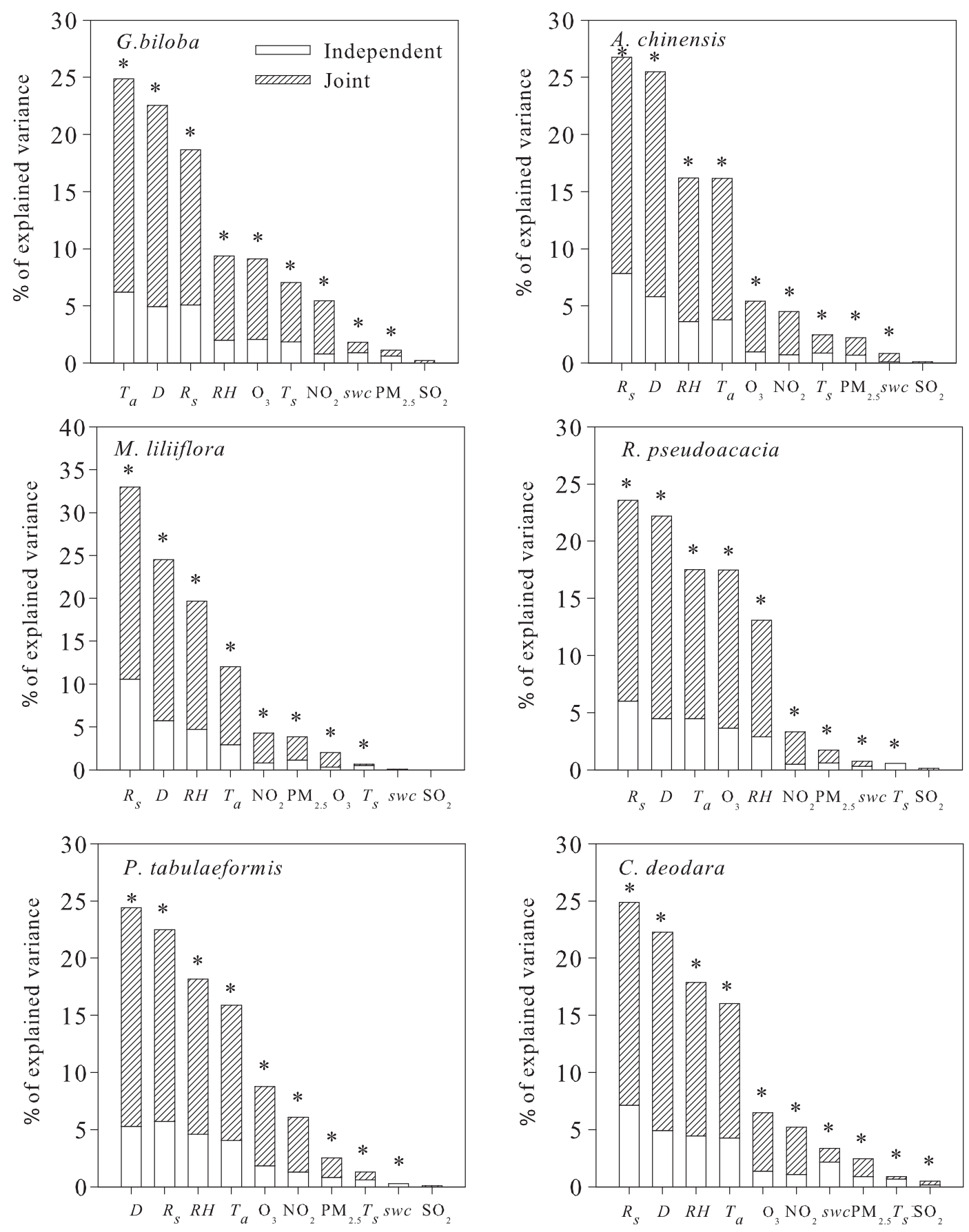

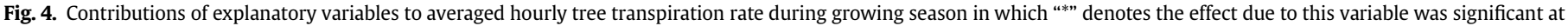
$p<0.05$.

research suggested that solar radiation controlled the shape of the diurnal flux in trees while daylight-averaged vapor pressure deficit controlled the magnitude of daily water uptake in a Panamanian moist forest (Phillips et al., 1999). The outcomes also indicated that the atmospheric pollution characterized by the concentrations of pollutant variables were simply an added minor stress factor in the urban environment (Tables 6 and 7). The microclimate conditions characterized by the water and heat variables in this case still were determinant factors governing the pattern of tree transpiration in urban settings. It appeared the processes controlling the transpiration of trees are essentially the same in urban or in natural setting.
Apparently the urban tree transpiration responded to changes of the water, heat, and pollutant variables independently as well as jointly (Tables 6 and 7). Both daily and hourly transpiration rates of trees in the urban environment were mainly influenced by combined effect of heat energy, water and airborne pollutant and combined effect of water and heat energy. In all, the environmental predictor groups accounted for an average \pm standard error of $77.6 \pm 4.6 \%$ and $67.5 \pm 3.4 \%$ of the total variance for averaged daily and hourly transpiration rates, respectively (Tables 6 and 7). There were lags and hysteresis taking place between onset of the environmental events and responses of trunk sap flow (Phillips et al., 1999). The phenomena would be more apparent and affect 
outcomes of the shorter hourly transpiration measurements rather than those at the longer daily time scale. The quadratic responses of hourly tree transpiration rate to changes of environmental variables (Table 5) were indications that the delays had caused the responses "piled up" at the later time. The lags and hysteresis occurring hour by hour would be smoothed out and averaged over the 24 hour transpiration cycle. As a result, the explanatory variables captured larger amount of the variances at the daily scale than those at the hourly scale. The undetermined variances were significant in both averaged daily and hourly transpiration rate measurements indicative of relevant variables such as canopy surface conductance, stand structure, and leaf area were not all accounted (Granier et al., 2000).

The variation partitioning provided only the qualitative assessment on contributions of the three groups of explanatory variables, while the hierarchical partitioning explicitly separated the contributions of individual explanatory variable in each group to the variance of tree transpiration (Figs. 3 and 4). The air temperature $\left(T_{\mathrm{a}}\right)$, soil temperature $\left(T_{\mathrm{s} 10}\right)$, total radiation $\left(R_{\mathrm{S}}\right)$, vapor pressure deficit $(D)$, and ozone $\left(\mathrm{O}_{3}\right)$ were the most important predictors for the daily transpiration rate of all tree species tested (Fig. 3). Variances of the averaged hourly tree transpiration rate were primarily caused by essentially the same environmental variables as those of the daily transpiration rates (Fig. 4). The influence of $T_{\mathrm{a}}, R_{\mathrm{s}}$, and $D$ on transpiration has been demonstrated by numerous studies (e.g. Granier et al., 1996; Huang et al., 2009). The hourly, compared to the daily, transpiration rate is a short duration measurement. It is notable to draw attention on the distinction between short vs. long term responses. Explanatory variables such as the soil temperature and soil water content had significant effects on daily transpiration rate of trees yet they exhibited little effects on the hourly transpiration rate of trees (Figs. 3 and 4). A certain soil temperature interacted with aboveground factors such as air temperature and length of daylight hours, was a factor in the restriction of transpiration (Mellander et al., 2004). The outcomes again showed that pollutant variables were considerably less important to tree transpiration rate in urban environment than the heat and water variables. More importantly, a far great portion of the explained effects were related to the joint contributions of explanatory variables (Figs. 3 and 4). It further confirms that the variations of tree transpiration rate were affected more by the combined rather than the independent effects of the explanatory variables.

Among the atmospheric pollutants, only the concentration of $\mathrm{O}_{3}$ had significant positive contributions to the tree transpiration rates of nearly every species and at both daily and hourly time scales (Figs. 3 and 4). The concentrations of $\mathrm{SO}_{2}, \mathrm{NO}, \mathrm{NO}_{2}, \mathrm{PM}_{2.5}$ were higher in winter, during which the urban tree transpiration was obviously damped (Figs. 1 and 2). Hence, these pollutants hardly affect urban tree transpiration (Figs. 3 and 4). The concentration of $\mathrm{O}_{3}$ was higher in summer, during which the urban tree transpiration increased (Figs. 1 and 2). At the presence of ozone, the leaves cuticle changes and greater stomatal apertures can lead to increased transpiration (Lee et al., 1990; Turunen and Huttunen, 1990; Schreuder et al., 2001). The AOT40 (accumulated exposure over a threshold of $40 \mathrm{ppb}$ ) during the growing season at our study site was $20.12 \mathrm{ppm} \mathrm{h}$, which far exceeded the current critical level for ozone impacts on forest trees of AOT40 $5 \mathrm{ppm} \mathrm{h}$ (UNECE, 2004). Adverse impacts of $\mathrm{O}_{3}$ on transpiration rate of urban trees appeared imminent. However, $\mathrm{O}_{3}$ is a secondary air pollutant, the resultant of atmospheric photochemical reactions of nitrous oxides. The heat energy brought about by intense solar radiation of the summer also would accelerate the trees' transpiration rate. The statistical significance might reflect the effect of $\mathrm{O}_{3}$ paralleled the effects of variables in heat energy related predictor group.

\section{Conclusions}

We investigated how microclimatic factors and air pollutants affected the hourly and daily transpiration rates of Ginkgo biloba Aesculus chinensis, Magnolia liliiflora, Robinia pseudoacacia, Pinus tabulaeformis, and Cedrus deodara in the urban settings of Beijing. The microclimatic factors and air pollutants were categorized into three groups of heat $\left(T_{\mathrm{a}}, T_{\mathrm{S}}\right.$, and $\left.R_{\mathrm{S}}\right)$, water $\left(D, \mathrm{RH}, \mathrm{SWC} C_{30}\right.$, and $\left.P\right)$, and pollutant ( $\mathrm{NO}, \mathrm{NO}_{2}, \mathrm{SO}_{2}, \mathrm{O}_{3}$, and $\mathrm{PM}_{2.5}$ ) variables. Our work demonstrated that both variation partitioning and hierarchical partitioning methods provide deeper insights into transpiration-environment relationships in urban trees than regression methods. The water and heat variables play a major role in the transpiration of urban tree, while air pollution variables act as an accelerator. We also depicted the contribution of single environmental variables for the transpiration of urban tree and showed the role atmospheric $\mathrm{O}_{3}$ concentration on the transpiration of urban tree. Moreover, majority of the variation in transpiration rates was associated with joint effects of groups of variables, especially heat and water variables. Understanding the transpiration-environment relationships can help to predict and manage urban tree water uses.

\section{Acknowledgments}

This study was supported by the National Natural Science Foundation of China (Grant No. 41030744), the Knowledge Innovation Program of the Chinese Academy of Science (Grant No. KZCX2-YW-422), the "11th Five-Year Plan" to support science and technology projects (Grant No. 2007BAC28B01), and Special Foundation of State Key Lab of Urban and Regional Ecology. We thank all the members of Beijing Urban Ecosystem Research Station and Beijing Teaching Botanical Garden for their assistance in the field. We especially thank Andrew C. Chang (University of California) for his valuable comments and helpful language polishing. Dr. Shengbin Chen (Chinese Academy of Sciences) provided helpful advice on data analysis.

\section{References}

Anderson, M.J., Cribble, N.A., 1998. Partitioning the variation among spatial, temporal and environmental components in a multivariate data set. Australian Journal of Ecology 23, 158-167.

Beijing Municipal Bureau of Landscape and Forestry, 2005. Collection of Beijing Urban Gardening and Afforestation Survey. Beijing Publishing House, Beijing.

Borcard, D., Legendre, P., Drapeau, P., 1992. Partialling out the spatial component of ecological variation. Ecology 73, 1045-1055.

Burgess, S.S.O., 2006. Measuring transpiration responses to summer precipitation in a Mediterranean climate: a simple screening tool for identifying plant wateruse strategies. Physiologia Plantarum 127, 404-412.

Campbell, G.S., Norman, J.M., 1998. An Introduction to Environmental Biophysics, second ed. Springer-Verlag, New York.

Costa, W., Amaratunga, K., Udumullage, R., 2006. Transpiration characteristics of some homegarden tree species in Central Sri Lanka. In: Kumar, B.M., Nair, P.K.R. (Eds.), Tropical Homegardens: A Time-Tested Example of Sustainable Agroforestry. Springer, Netherlands, pp. 251-267.

Fan, M., Ma, L.Y., Wang, R.H., 2008. Variation of stem sap flow of Robinia pseudoacacia in spring and summer. Scientia silvae Sinicae 44, 41-45.

Fernandez, M.E., Gyenge, J., Schlichter, T., 2009. Water flux and canopy conductance of natural versus planted forests in Patagonia, South America. Trees-Structure and Function 23, 415-427.

Granier, A., 1987. Evaluation of transpiration in a Douglas-fir stand by means of sap flow measurements. Tree Physiology 3, 309-320.

Granier, A., Huc, R., Barigah, S.T., 1996. Transpiration of natural rain forest and its dependence on climatic factors. Agricultural and Forest Meteorology 78, 16-29.

Granier, A., Loustau, D., Bréda, N., 2000. A generic model of forest canopy conductance dependent on climate, soil water availability and leaf area index. Annals of Forest Science 57, 755-765.

Hagishima, A., Narita, K., Tanimoto, J., 2007. Field experiment on transpiration from isolated urban plants. Hydrological Processes 21, 1217-1222.

He, S.Y., Xing, Q.H., Yin, Z.T., Jiang, X.F., 1993. Flora of Beijing. Beijing Publishing House, Beijing. 
Heikkinen, R.K., Luoto, M., Kuussaari, M., Pöyry, J., 2005. New insights into butterfly-environment relationships using partitioning methods. Proceedings of the Royal Society of London, Series B: Biological Sciences 272, 2203-2210.

Heikkinen, R.K., Luoto, M., Virkkala, R., Rainio, K., 2004. Effects of habitat cover, landscape structure and spatial variables on the abundance of birds in an agricultural-forest mosaic. Journal of Applied Ecology 41, 824-835.

Huang, Y.Q., Zhao, P., Zhang, Z.F., Li, X.K., He, C.X., Zhang, R.Q., 2009. Transpiration of Cyclobalanopsis glauca (syn. Quercus glauca) stand measured by sap-flow method in a karst rocky terrain during dry season. Ecological Research 24, 791-801.

Lee, W.S., Chevone, B.I., Seiler, J.R., 1990. Growth and gas exchange of loblolly pine seedlings as influenced by drought and air pollutants. Water, Air, and Soil Pollution 51, 105-116.

Lu, P., Yunusa, I.A.M., Walker, R.R., Müller, W.J., 2003. Regulation of canopy conductance and transpiration and their modelling in irrigated grapevines. Functional Plant Biology 30, 689-698.

Ma, D., Li, J.Y., Lin, P., 2006. Primary studies on water consumption of man-made forest in mountain area in Beijing. Journal of Shanxi Agriculture University 26, 48-51.

MacNally, R., 1996. Hierarchical partitioning as an interpretative tool in multivariate inference. Australian Journal of Ecology 21, 224-228.

McLaughlin, S.B., Wullschleger, S.D., Sun, G., Nosal, M., 2007. Interactive effects of ozone and climate on water use, soil moisture content and streamflow in a southern Appalachian forest in the USA. New Phytologist 174, 125-136.

Mellander, P.E., Bishop, K., Lundmark, T., 2004. The influence of soil temperature on transpiration: a plot scale manipulation in a young Scots pine stand. Forest Ecology and Management 195, 15-28.

Montague, T., Kjelgren, R., 2004. Energy balance of six common landscape surfaces and the influence of surface properties on gas exchange of four containerized tree species. Scientia Horticulturae 100, 229-249.

Neighbour, E.A., Cottam, D.A., Mansfield, T.A., 1988. Effects of sulphur dioxide and nitrogen dioxide on the control of water loss by birch (Betula spp.). New Phytologist 108, 149-157.

Nowak, D.J., Dwyer, J.F., 2007. Understanding the benefits and costs of urban forest ecosystems. In: Kuser, J.E. (Ed.), Urban and Community Forestry in the Northeast. Springer Science and Business Media, New York, pp. 25-46.

O’Brien, J.J., Oberbauer, S.F., Clark, D.B., 2004. Whole tree xylem sap flow responses to multiple environmental variables in a wet tropical forest. Plant, Cell \& Environment 27, 551-567.
Pataki, D.E., Oren, R., 2003. Species differences in stomatal control of water loss at the canopy scale in a mature bottomland deciduous forest. Advances in Water Resources 26, 1267-1278.

Phillips, N., Oren, R., Zimmermann, R., Wright, S.J., 1999. Temporal patterns of water flux in trees and lianas in a Panamanian moist forest. Trees - Structure and Function 14, 116-123.

Schreuder, M.D.J., van Hove, L.W.A., Brewer, C.A., 2001. Ozone exposure affects leaf wettability and tree water balance. New Phytologist 152, 443-454.

State Statistical Bureau, 2008. Statistical Yearbook of Beijing 2008. China Statistics Press, Beijing.

Teodoro, A., Klein, A., Tscharntke, T., 2008. Environmentally mediated coffee pest densities in relation to agroforestry management, using hierarchical partitioning analyses. Agriculture, Ecosystems \& Environment 125, 120-126.

Turunen, M., Huttunen, S., 1990. A review of the response of epicuticular wax of conifer needles to air pollution. Journal of Environmental Quality 19, 35-45.

UNECE, 2004. Manual on methodologies and criteria for modelling and mapping critical loads \& levels and air pollution effects, risks, and trends. United Nations Economic Commission for Europe (UNECE) Convention on Long-range Transboundary Air Pollution, Geneva, Switzerland, pp. 54.

Van Bavel, C.H.M., Fritschen, L.J., Reeves, W.E., 1962. Transpiration by Sudangrass as an externally controlled process. Science 141, 269-270.

Walsh, C., MacNally, R., 2003. The hier.part package. Hierarchical Partitioning. R project for statistical computing. URL: http://cran.r-project.org/.

Wang, K.Y., Kellomäki, S., Zha, T., Peltola, H., 2005. Annual and seasonal variation of sap flow and conductance of pine trees grown in elevated carbon dioxide and temperature. Journal of Experimental Botany 56, 155-165.

Xia, G.M., Kang, S.Z., Li, F.S., Zhang, J.H., Zhou, Q.Y., 2008. Diurnal and seasonal variations of sap flow of Caragana korshinskii in the arid desert region of northwest China. Hydrological Processes 22, 1197-1205.

Xiao, R.B., Ouyang, Z.Y., Zheng, H., Li, W.F., Schienke, E.W., Wang, X.K., 2007. Spatial pattern of impervious surfaces and their impacts on land surface temperature in Beijing, China. Journal of Environmental Sciences 19, 250-256.

Zeppel, M.J.B., Yunusa, I.A.M., Eamus, D., 2006. Daily, seasonal and annual patterns of transpiration from a stand of remnant vegetation dominated by a coniferous Callitris species and a broadleaved Eucalyptus species. Physiologia Plantarum $127,413-422$.

Zhao, P., Rao, X.Q., Ma, L., Cai, X.A., Zeng, X.P., 2005. Application of Granier's sap flow system in water use of Acacia mangium forest. Journal of Tropical and Subtropical Botany 13, 457-468. 